\title{
Extricating the Restrictive Aspects of Implementing Mobile-Commerce
}

\author{
Aiman J. Albarakati \\ Department of Computer Engineering, \\ College of Computer and Information Science, \\ Majmaah University, Majmaah, Saudi Arabia
}

\begin{abstract}
With the recent year's steps forward and progressive growth in M-Technology (Mobile Technology), an assortment of business activities can be coordinated through remote frameworks (Wireless Networks). Mobile Commerce (MCommerce) is experiencing quick advancement to the extent capacities of phones, services, applications, network and standard execution. Regardless, this speedy change of M-Tech and the advancement of Mobile Commerce models are reflected about low in Mobile Commerce determination rate. We have outlined here that the modeling of the income streams among the business segment players is the basic role behind low determination/adaption rate.
\end{abstract}

\section{Keyword}

Mobile Technology, Mobile Commerce, Networks, Implementation

\section{INTRODUCTION}

In modern decades, we have observed E-commerce implementation and thinning out both in B2B (Business to Business) and B2C (Business to Customer) associations. Along these lines, this affirmation has realized foremost propel in procedures, necessities, and headway of the applications and services of E-commerce. Evidently, all Ecommerce applications are in perspective of wired base. This cutoff, subsequently, prompts the longing of more conservativeness and versatility for empowering business trades. Consequently, this prompts the improvement of MCommerce hold up by movement in remote advances (Wireless Technologies). Mobile Commerce can be portrayed as the conduct of business maintained by remote advancements or wireless technologies. The most tremendous purpose of interest that Mobile Commerce offers is the convenience that supports customers cooperating trades and bringing into play services paying little personality to their physical territories. Researches' bring into being that specifically cell phones were a champion amongst the most quickly grasped buyer things [1]. At present, more than 800 million cell phones and other PDAs are being utilized far and wide. The general numbers are expected to rise to one billion soon, thusly surpassing the combined total of each figuring contraption [2]. Meanwhile, the adaptable telecom frameworks/networks, for instance, General Packet Radio Service (GPRS, Commonly suggested as 2.5G), Enhanced Data Rates for Global Evolution (EDGE, Commonly insinuated as 2.75G), Code Division Multiple Access 2000EVDO (CDMA2000-EVDO, usually implied as one kind of 3G and Wideband Code Division Multiple Access (WCDMA, normally suggested as one sort of $3 \mathrm{G}$ have been created rapidly. Nations that nonappearance of typical telecom establishment are at risk to grasp remote and adaptable correspondences/communications to serve both urban and commonplace areas. Experiences exhibit a quick addition in adaptable supporters: from two billion in year 2005 to approximately 3.3 billion by year 2010 [3]. A research by the Wireless Data and Computing Service of Strategy Analytics expected that trades by method for cells make about $\$ 14$ billion consistently [2]. This data induces the creating noteworthiness of convenient advancement or M-Technology and applications despite the current services and applications, comprising SMS and charging. It similarly prescribes generous business prospects and impending profit in mobile commerce. To catch this opportunity, it is basic for the business to pass on suitable arrangements of activity and appreciate the drivers and inhibitors of implementing mobile commerce. Hereafter, the inspiration driving this study is to investigate the current mobile commerce arrangements of activity and perceive segments that affect the gathering of mobile commerce by glimpsing over at the purposes of interest and weaknesses of on hand model arrangements.

\section{BUSINESS MODELS OF MOBILE- COMMERCE}

The classification by [4] has been assumed here to portray the articulation Business Model as a model of mobile service prerequisite, comprising unmistakable confirmation of business entertainers and examination of pay streams. This definition/classification puts particular highlight on the revenue stream among the business segment players. It has been demonstrated the outline of the mobile commerce strategies of activity model: a vital model and distinctive models when assorted developments were situated up, specifically in the $2 \mathrm{G}$ era and past.

In the crucial model, the outcast services and application suppliers were estranged from the MNOs. This prompts more business open entryways from the business point of view, and also more available services from the customers' viewpoint. Exactly when $2 \mathrm{G}$ framework/network was the vital framework being utilized, the framework. Suppliers and services and applications suppliers were bundled together. Framework/network suppliers and equipment merchants were able to develop the applications and services. Consequently, the amount of 3rd party services and application suppliers was restricted. The services presented by framework/network suppliers were passed on to customers in light of participation offerings. [4] Portrayed this model as a strict operator-centric model. The restrictions/limitations were predominantly realized by: 
i. Constraints on sorts of systems to get take-home pay or income - Generally, this is because $2 \mathrm{G}$ service operates bestowed near to voice organizations and SMS [5].

ii. Constraints on kind of services bestowed - From the customers' viewpoint, the fundamental services on hand to them are for crafting connection of telephone sending SMS.

iii. Pricing issue - In a couple of countries, government deals with the services to be given by one or not a lot of MNO, bringing on high participation charge on account of the nonattendance of forcefulness in the business division.

Right when $2.5 \mathrm{G}, 2.75 \mathrm{G}$ and $3 \mathrm{G}$ systems are open, new mobile commerce strategies of activity or model rise. These models upgrade the past model by removing the dependence between getting to applications and services and subscribing to framework/network suppliers. Three crucial models that ascent with the more present period framework/network turn around framework/network operator, service aggregator and service supplier.

\subsection{The Network Operator Centric Model}

The customer subscribe to a mobile network operator here in this model, which is fit to give customers telecom services, and pass on services and applications offered by any of outcast players. Likewise, the framework/network operator is also accountable for charging and charging errands. The mobile framework supplier circulates the revenue among each included player [4]. In summary, the mobile network operator is the standard entertainer for service and content aggregator, framework transport supplier, charging and payment supplier.

\subsection{Content and Service Aggregator Centric Model}

In this model, the content and service aggregator is responsible for outfitting customers with its own particular applications and services. Additionally, it moreover offers access to applications and services offered by outcast independent services and applications suppliers. It is acknowledged that the content and service aggregator comes into particularly simultaneousness with a framework/network supplier for passing on content and services through the framework/network supplier's infrastructure. The customers need to subscribe to both the content and service aggregator and an adaptable framework supplier. Regardless, picking mobile framework supplier is made unreservedly from picking the content and service aggregator. Considering the participation, the content and service aggregator describes the expenses, accumulates the charging information and charges the customer in light of both transport part and content and service parts. By then, the dispensing of livelihoods among mobile framework suppliers, content and service suppliers and content and service aggregator is performed by content and service aggregator in perspective of the assentions assembled among the players. This infers that in this model, content and service aggregator endeavors the piece of charging and portions suppliers. In this model, instead of the content and service aggregator, the content and service suppliers come direct into simultaneousness with framework supplier for passing on their applications and services through the last's telecom system. The content and services suppliers portray the esteeming and portion methodologies and charge the customers in perspective of their usage of transport and content and service. From this model perspective, the customers come to participation simultaneousness with the content and service supplier, which joins the parts of content and service aggregator and charging and billing supplier. Additionally, the content and service supplier assembles and dispenses the wage among the included players as showed by business assentions. The probability the framework operators to charge the customer autonomously for the vehicle part is not blocked [4].

\section{INFLUENTIAL ASPECTS OF MOBILE COMMERCE IMPLEMENTATION}

Four clarifications behind today's low allotment rate of mobile commerce are high outlay, advancement improvement, innovative services acquisition, and productive approaches in pricing and billing technique.

\subsection{Outlay}

Mobile Commerce meets expectations inside the paid-for service framework in the private cell phone industry where business competition is firm. In binging into play services of this telecommunications, customers pay for airtime, by the measure of the data packet transmitted, and by the service brought into play for what they get [6]. At present, overall remote/wireless frameworks are partitioned and guaranteed by various mobile operators. [7] outlined that appeared differently in relation to the simplicity for web get to, a specific typical for mobile commerce is the high cost of the framework/network structure. Communication of mobile through cell phones is extravagant, and any additional applications and services lead to extra charges. The reason is that the establishment of an adaptable correspondence framework obliges overpowering business wander [8] Thusly, mobile commerce players must create income by coordinating business activities to legitimize the enormous basic hypothesis [9]. Tantamount perspective can in this way be progressed on the expense of applications and services. The change and movement of applications and services furthermore require starting endeavor. This suggests the applications and services suppliers must scan for income from offering the applications and services. Tragically, these costs of mobile framework utilization, and applications and services transport must be gone ahead to clients. This towering cost/outlay is undesirable in light of the way that cost has been a fundamental part considered by clients when picking whether to share in mobile commerce [10]. [11] outlined that, when changing to unmistakable things or online services, customers must oversee non-superfluous costs." Obviously, determination of mobile commerce at first induces costs, for instance, gear [12]. Joining with the cost of enrollment and utilizing the applications and services, in mobile commerce models, we can watch that cost affects the allocation of mobile commerce, which direct effects the efficiency of models of mobile commerce. On the other hand, it is extremely typical that the applications and services and supplies which unite the latest development reliably cost more than things with created advancement. Yet high cost may keep customers from enduring new applications and services, nonappearance of applications and services may similarly provoke low exercise. 


\subsection{Advancement Improvement (Technology)}

Mobile Commerce services are propelled by a blended sack of remote/wireless media correspondence or communication standards reaching out from around the world (Satellite), neighborhood (3G, IEEE 802.11a/b, DoCoMo I-mode), to short detachment or Bluetooth (Shim and Rice, 2001). Mobile framework suppliers bring into play contrary systems and models, for instance, GSM (Global Service for Mobile), TDMA (Time Division Multiple Access), and CDMA (Code Division Multiple Access) to adversary each other (Leung and Antypas, 2001). Because of unmistakable models of development, mobile commerce applications tend to be device and framework/network subordinate. Investigations dig out that there has been no nonexclusive general framework and standard for application change utilizing exclusive/worldwide mobile connections and access. This realized the slower-thanexpected gathering of mobile commerce [7]. Disregarding the test in unmistakable framework benchmarks, variety exchange pace is an essential issue. Starting late, the multi-band and multi-mode cells have created, allowing trades between frameworks. Ordinary envoys are the twofold band cell phones that have the ability to exercise $900 \mathrm{MHz}$ and 1800 MHz GSM frameworks. Moreover, there are services that can employ WLANs and Bluetooth, together with GSM, GPRS, and $3 \mathrm{G}$ frameworks. Nevertheless, remote/wireless progressions change on the level of information exchange limit and reliability they give. On one hand, this limits the sorts of applications and services that can be given, for occasion, mobile TV that obliges high exchange speed. Of course, it influences moderate, flawed affiliations/connections, or poor affiliation quality - achieving unsatisfying customer experience. Furthermore, in a couple of frameworks and for a couple of services, costs are charged each affiliation/connection time, while for others, for instance, in packet radio, it is charged each packet or message [13]. The inconveniences in frameworks quality, for instance, ceaseless sudden separation may particularly incite increase in charges, which comes to fruition unfavorably for mobile commerce adopters. Despite essential frameworks organization system and benchmarks, it is the client contraptions that truly make sense of what applications and services can be passed on. Mobile-commerce applications rely on upon the exercise of cells. Cell phones, as the guideline Mobile-Commerce device, can be confined into four arrangements in light of their processor, memory and battery limit, application limits (SMS, WAP, Web, I-mode) furthermore physical size and weight [14]. These classes are (from weakest to strongest): typical voice handsets with SMS capacity, WAP phones, communicators or PDA with remote/wireless communication limit, ultimately mobile PCs with remote correspondence workplaces. On one hand, to perform adaptability, devices must be physically light and little. Smallness considerations, in conjunction with a given cost and level of advancement, will keep mobile segments having less resources than static elements. This comprises humbler memory, capacity of disk and computational power than customary figuring contraptions. Moreover, cells, for instance, cell phones have little screens with limited presentation locale. In spite of the way that WAP devices support a compelled configuration association called Wbitmap, because phones had limited information exchange limit and little screens, any application that is energetically reasonable or development driven would not be suitable starting at this point. Additionally, programming applications are by and large grungy. There are no treats or session controls, suggesting that if the affiliation is lost, the application will need to restart as opposed to having the ability to continue from past screens [15]. The web browsers and drop-down menus are diverted, so associations must mull over on character-based terminal applications with cursors and key passageway shapes. Long decision records or significant menu layers will pulverize the fingers of even the most patient customers [16].

\subsection{Innovative Services Acquisition}

With the support of the versatile establishment, organizations and applications can be passed on to customers. Market players including framework suppliers, organization and substance suppliers, get pay in light of usage of these organizations and applications. Exploration by [17] assumed that wide accessibility of the web expect a noteworthy part in E-commerce accomplishment. Powerful and created PC systems enable looking and transport of a blended pack of complex services and applications, and trade changing to be done smoothly. Diverged from E-Commerce, the transport of Mobile-Commerce applications relies on upon private framework/network suppliers. Services are ordinarily open specifically region, and are less mind boggling, more tweaked, range specific and time-sensitive [17]. Since phones consistently stay close-by to proprietors at whatever point and wherever, it is acknowledged that mobile commerce makes a more private environment diverged from E-Commerce practices which may happen on any open PCs. [18] affirmed that: time tricky, fundamental trades, for instance, film ticket purchases, keeping cash, and travel reservations are acknowledged to be the key applications that will enable mobile business. Other imperative applications and services which drive mobile commerce improvement are region based applications, for instance, pilgrim course and emergency response [19][20][21][22]. The essential qualification between mobile commerce applications, services and customary Ecommerce applications and services is that the change and execution of applications and services should abuse the traits of the available compact frameworks and contraptions. As sketched out by [17], the arrangement of a successful applications and services should take thought on five components e.g. transportability for instance in adaptable correspondence, region sensitive for instance in travel course, Time-separating for instance in flight arranges, individual character for instance, in electronic portions, phenomenal business part corner concentrated on for instance in organizations uniquely designed to specific country. Thus, we can reason that imaginative and supportive applications and services are imperative for suppliers to draw in voluminous utilization. Also, the sort, quality and organization fit will direct effect the customer affirmation.

\subsection{Dilemmas of Pricing and Billing}

Investigation by [4] recommended that the utilization of a charging protocol for the exchanging of real time charging and consent information is critical for mobile business, especially in case of roaming. This dispute accordingly raises another component that is critical to mobile business allocation, to be particular how to administer esteeming and charging effectively. From the customers' point of view, straightforwardness, for instance, in the one-quit charging, is alluring. In any case, as differing framework suppliers and application and services suppliers have element part in the services provisioning and offering things under their own 
specific setting, the assessing and charging structures should be changed to fit each of these suppliers. A case to disentangle this controversy and temporary route the probability of a convoluted assessing model is the layered charging auxiliary arranging proposed by [23]. This anticipated model embodies three layers: transport, service and application, each expected for regulating and taking care of imperative information at each layer. Besides, assorted evaluating models should be associated on every charging layer. A valid example, the associated esteeming or applied pricing model can be: costbased, enrollment/subscription based or fixed charges, duration or time-span based, volume-based, service based, zone/location based, or event based. Moreover, the evaluating/pricing of a service may be in light of one or a couple of the going hand in hand with properties: type of network, contraption limits, nature/quality of service, service end pointer. Charges can be made depending upon why, when or where an service was abnormally finished, trade sort (getting a certain sort of message may have a specific quality), content supplier, content aggregator or framework operator character. This model is great from the self-ruling suppliers' perspective, in light of the way that they can then set their own particular assessing game plan for the utilization of service.

\section{SUMMARY}

An assortment of Mobile-Commerce strategies plans or models has been described here that delineate the wage/income streams among the business players in mobile commerce. In making a remark on this example, an examination on the E-commerce setting and the Mobile Commerce association has been presented. In E-commerce, beside the genuine expense of the service and things, the framework/network cost is all that much passed on among the web customers. As a resulting, content suppliers can dispatch engaging income/revenue models, comprising free storage space and free email to draw in clients to their destinations. One significant clarification behind beneficial E-commerce model is because of the web advancement is not as radical as the remote/wireless development, for instance, 3G, $4 \mathrm{G}$ and earlier period. It has been acknowledged that the revenue or income streams in Mobile Commerce model are so far changing in journey for the best model that result in benefit for the suppliers and insignificant exertion for the purchasers. Moreover it has been pointed out that advancement (technology) progress accept a key part in Mobile Commerce gathering. Taking pro of development and refusing deficiency in vacant specific condition are essential to upgrade the viability of Mobile Commerce model. A valid example, if fast framework/network is not open in a couple of reaches, then services of mobile television can't be passed on. Diverse variables or aspects that impact Mobile Commerce implementation comprise: corner position of each player in the trust and service quality and value chain, trust among players as payment and endorsement are key edges in the mobile business establishment; and service nature or quality to ensure that the bestowed services fulfill the longing customers' longings.

\section{REFERENCES}

[1] de Haan, A. 2000. The internet goes wireless. eAI Journal, April, pp. 62-63. ePaynews.com. 2004. Statistics for Mobile Commerce. Available from: http://www.epaynews.com/statistics/mcommstats.html.
[2] Vetter, R. and Varshney, U. 2002. Mobile commerce: framework, applications and networking support. Mobile Networks and Applications, vol. 7, no. 3, pp. 185-198.

[3] Tilak, J. 2006. 3.3bn global mobile phone subscribers by 2010 - report. DMEurope.com. Available from: http://www.dmeurope.com/default.asp?ArticleID=15236.

[4] Panagiotakis, S., Koutsopoulou, M. and Alonistioti, A. 2005. Business Models and Revenue Streams in 3G market. National and Kapodistrian University of Athens, Department of Informatics and Telecommunications, Communication Networks Laboratory, 15784 Athens, Greece. Available from: http://cgi.di.uoa.gr/ mkoutsop/data/Panagiotakis_Summi t2005_almost_final.pdf.

[5] Peersman, C., Cvetkovic, S., Griffiths, P. and Spear, H. 2000. The global system for mobile communications short message service. Personal Communications, IEEE, vol. 7, Issue 3, pp. 15-23.

[6] Fox, J. 2000. A river of money will flow through the wireless Web in coming years. All the big players want is a piece of the action. Fortune, vol. 142, no.8, pp.140-146.

[7] Shim, R. and Rice, V. 2001. How to unwire your business. Technology Review, Special Issue of Fortune, pp. 46-54.

[8] Ramakrishnan, J. 2001. WWWireless wonder. Corporate Location, Mar/Apr 2001, pp. 60-61.

[9] Lamont, D. 2001. Conquering the wireless world, the age of m-commerce. Capstone Publishing Limited (A Wiley Company).

[10] Plouffe, C. R., Hulland, J. S. and Vandenbosch, M. 2001, Research report: richness versus parsimony in modeling technology adoption decision-understanding merchant adoption of a smartcard based payment system. Information Systems Research, vol. 12, issue 2 pp. 208 222.

[11] Chen, P. Y. and Hitt, L. M. 2002. Measuring switching costs and the determinants of customer retention in Internet-enabled businesses: a study of the online brokerage industry. Information Systems Research, vol. 13 , issue 3, pp. 255-274.

[12] Constantinides, E. 2002. The 4 S Web-marketing mix model, electronic commerce research and applications. Elsevier Science, vol. 1, issue 1, pp. 57-76. International Telecommunication Union 2007, Accessed 24 March, 2007 ,

[13] Wu, J. H. and Wang, S. C. 2004. What drives mobile commerce? An empirical evaluation of the revised technology acceptance model. Information \& Management, vol.42, issue 5, pp.719-729.

[14] Tsalgatidou, A. and Pitoura, E. 2001. Business models and transactions in mobile electronic commerce: requirements and properties. Computer Networks, vol. 37 , issue 2, pp. 221-236

[15] Leung, K. and Antypas, J. 2001. Improving returns on mcommerce investments. The Journal of Business Strategy, vol. 22, no. 5, pp.12-13. 
[16] Moustafa, N. 2000. Worry-less wireless. Wireless Review, vol. 17, no. 22, pp.30-32.

[17] Zhang, J. J., Yuan, Y. F. and Archer, N. 2002. Driving forces for m-commerce success. Michael G. DeGroote School of Business, McMaster University, Hamilton, Ontario, Canada.

[18] Lucas, P. 2001. M-commerce gets personal. Credit Card Management, vol. 14, no.1, pp.24-30.

[19] Secker, M. 2001. Does m-commerce know where it's going?. Telecommunications, vol. 35, no.4, pp. 85-88.

[20] Rockhold, J. 2001. Find your location reality. Wireless Review, pp. 6-8.
[21] Swartz, N. 2001-1. Taking it to the street. Wireless Review, vol. 18 , no. 5, pp. 54-58.

[22] Swartz, N. 2001-2. Hot \& cold: m-commerce opportunities', Wireless Review, vol. 18, no. 6, pp. 3238 .

[23] Koutsopoulou, M., Kaloxylos, A., Alonistioti, A., Merakos, L. and Philippopoulos, P. 2004. An integrated charging, accounting \& billing management platform for the support of innovative business models in mobile networks. International Journal of Mobile Communications (IJMC), vol. 2, no. 4, pp. 418-434. 